Article

\title{
Sustainable Wellbeing Operationalization and Measurement Based on the Capabilities Approach: The Case of Latin America
}

\author{
Jhoner Perdomo $^{1, * \mathbb{C}}$, Mauricio Phélan Casanova ${ }^{1}$ and Sary Levy-Carciente ${ }^{1,2}$ \\ 1 Institute of Economic and Social Research, Central University of Venezuela, Caracas 1051, Venezuela; \\ mauphelan@gmail.com (M.P.C.); saryle@yahoo.com (S.L.-C.) \\ 2 National Academy of Economic Sciences, Caracas 1010, Venezuela \\ * Correspondence: jhonerperdomo@gmail.com
}

Citation: Perdomo, J.; Phélan

Casanova, M.; Levy-Carciente, S.

Sustainable Wellbeing

Operationalization and Measurement Based on the Capabilities Approach:

The Case of Latin America.

Sustainability 2021, 13, 12202 .

https://doi.org/10.3390/su1321 12202

Academic Editors:

Filomena Maggino, Leonardo Salvatore Alaimo, Enrico Di Bella, Marco Fattore and Matteo Corsi

Received: 20 August 2021

Accepted: 27 October 2021

Published: 5 November 2021

Publisher's Note: MDPI stays neutral with regard to jurisdictional claims in published maps and institutional affiliations.

Copyright: (๑) 2021 by the authors. Licensee MDPI, Basel, Switzerland. This article is an open access article distributed under the terms and conditions of the Creative Commons Attribution (CC BY) license (https:// creativecommons.org/licenses/by/ $4.0 /)$.

\begin{abstract}
Starting from the capabilities approach, this work develops the concept of sustainable wellbeing, which highlights the importance of incorporating temporal sustainability into the analysis of wellbeing, with intergenerational justice. For its measurement, 12 dimensions are identified and defined, based on the philosophical approach of central capabilities of Martha Nussbaum. The measurement is applied to 18 Latin American countries, with 116 indicators, using a multiple correspondence analysis (MCA). The results show the viability of operationalizing the capabilities approach and its potential to support the formulation of associated policies.
\end{abstract}

Keywords: capabilities approach; statistical indicators; human development; sustainability; wellbeing

\section{Introduction}

In this work, sustainable wellbeing is presented as a proposal that attempts to answer some current questions in the face of the challenges that will arise for future generations. Sustainable wellbeing becomes a way of carrying out individual life, but is also a political issue, involving both corporations and the state. In this sense, sustainable wellbeing emerges as a new alternative and complementary approach to models and measures that integrate the two key notions of wellbeing and sustainability. This is because a development model cannot be considered as a generator of well-being if it is not sustainable over time, where individuals cannot consider having acceptable wellbeing without considering others, even future generations. The objective of this work is to present and operationalize the concept of sustainable wellbeing, based on the approach of the capabilities of Amartya Sen and the approach of the central capabilities of Martha Nussbaum.

This work is structured in four parts. First, the definition of the approach is presented within the framework of the discussions that have taken place in this regard. Second, a proposal is put forward for its operationalization, and thus its measurement, as a precondition for the implementation of policies based on the approach. Sustainable wellbeing adopts 12 dimensions, originating from the 10 central capabilities of M. Nussbaum. Measurement is carried out using multiple correspondence analysis (MCA). Third, a proposed index applied to 18 Latin American countries is presented. The results show the viability of the operationalization of the concept and its capacity to support the formulation of policies. This can be replicated following the steps of the method at any level, from a comparison of countries (as is the case in the present essay), local governments, corporate governance, and even individual way of life. Finally, a discussion on three aspects of the proposal-the concept, the dimensioning, and the statistical measurement—is presented.

\section{Sustainable Wellbeing}

The need to update and propose new development approaches is an effort that has been ongoing for several decades [1-24]. Some of these contributions can be found, for example, in the Cocoyoc Declaration in 1974 [4]; in the results of the Brundtland 
Commission report [14]; and in the 1990s, mainly with the Human Development Index [3]. The first decade of the 21st century saw the European Commission report (2009) [1] "GDP and beyond. Assessment of progress in a changing world" and the results of the StiglitzSen-Fitoussi Commission (2009) [2] "Report of the Commission on the Measurement of Economic Development and Social Progress". Already, in the second decade of the 21st century, some guidelines have been officially consolidated, from the UN (2012) [18] with the report "The future we want for all"; followed by the report on "A new global alliance" (2013) [17]; and finally the 2030 Agenda (2015) [15]. The United Nations also carried out actions concerning the climate with the Paris Agreement (2015) [16] and the report of the "Global warming of $1.5^{\circ} \mathrm{C}$ " (2018) [20]. Finally, in 2020, the European Union began with the strategy for climate action [7].

The Anthropocene era has generated substantial impacts on the environment, with climate change being a highlight, which in turn influences wellbeing, even endangering our survival as a species. This necessitates the seeking of new approaches to wellbeing and human development. We must think about how to not only modify our life and adaptation on our planet, but also change our conception of life (wellbeing, quality of life, better life, happiness, and development, among others). We must incorporate the idea that wellbeing over time will be based on what we decide in the present. The importance of the individual in achieving sustainability is highlighted. An alternative is to combine present wellbeing with future wellbeing, incorporating sustainability; this is seen as a multidimensional concept within which capabilities prevail $[25,26]$. By incorporating the future perspective into conceptions of wellbeing, intergenerational responsibility is imposed.

In this way, the perspective of sustainable wellbeing emerges as a complementary approach to the models and measurements that have been carried out, for which it is important to consider a brief historical overview of the measurements of development. There are three historical periods. The first is the stage that emphasizes economic growth, with GDP as a marker of development. The second begins with the arrival of the Brundtland Commission report and the Human Development Index (HDI) in the 1990s, which consolidated the expansion of dimensioning, in order to open the way to sustainability and human development [27]. The third moment is marked by the conference "Beyond GDP" in 2007 with the support of the European Commission, the subsequent report "GDP and beyond" in 2009, and the recommendations issued by the Stiglitz-Sen-Fitoussi Commission in that same year, which stimulated the creation of a series of measurements [27].

Among the measurements associated with this third historical period, we have the following: the Eurostat Quality of Life and the OECD Better Life Index, followed by measurements such as the Social Progress Index, the Sustainable Economic Development Assessment (SEDA), and the Legatum Prosperity Index. In this historical period, freedom acquires special relevance as a component of the development and enhancement of human capabilities (A 2020 report by the international organization SELA [27] has compiled a total of 104 indicators and has initially detailed a total of 40).

In the context of the third historical period of measurements, the main contribution of sustainable wellbeing is to integrate two notions that are so far separated, that is, wellbeing and sustainability, expanding on the conception and dimensioning of sustainable development. Sustainable development seeks to combine three dimensions: economic, social, and environmental. On the other hand, sustainable wellbeing seeks to increase the multidimensional spectrum of aspects associated with the wellbeing of individuals and their relationship with temporality (sustainability), including environmental, economic, and social aspects, among other dimensions (12 dimensions), integrating them in harmony to achieve balance. Sustainable wellbeing is based on the idea that a development model considered as a generator of well-being must be sustainable over time. Adopting the joint perspective of the two notions, wellbeing and sustainability, also allows to promote comprehensive and responsible results with oneself and with others, incorporating moral elements, such as rights and intergenerational justice. 
Sustainable wellbeing is inspired by the central capabilities approach of Martha Nussbaum [25] and in the conception of sustainability proposed by Amartya Sen, where he mentions that sustainability is to enhance the capabilities of the present generation, without compromising the capabilities of future generations [26]. In this way, the hypothesis is that, to the extent that there are greater capabilities, opportunities, and freedoms, there will be greater possibilities for these conditions to achieve sustainability. Likewise, there will be more guarantees, such that people can be who they want to be and do what they value, increasing their freedom and wellbeing. Then, sustainable wellbeing considers future risks based on the sustainability over time of the present conditions, which in turn are based on the accumulation of existing capabilities.

However, for this approach to be operational, it is necessary to measure it-a necessary step for the implementation of policies at any scale of interest. In the following section, the operationalization and measurement process will be presented.

\section{Method}

Based on the central capabilities approach of Martha Nussbaum [25], 12 dimensions, grouped in 4 macro-dimensions, were considered as components of sustainable wellbeing (see Figure 1). Subsequently, the indicators associated with each of the dimensions were identified [28]. Finally, these results are integrated into the macro-dimensions until reaching the final aggregate of sustainable wellbeing.

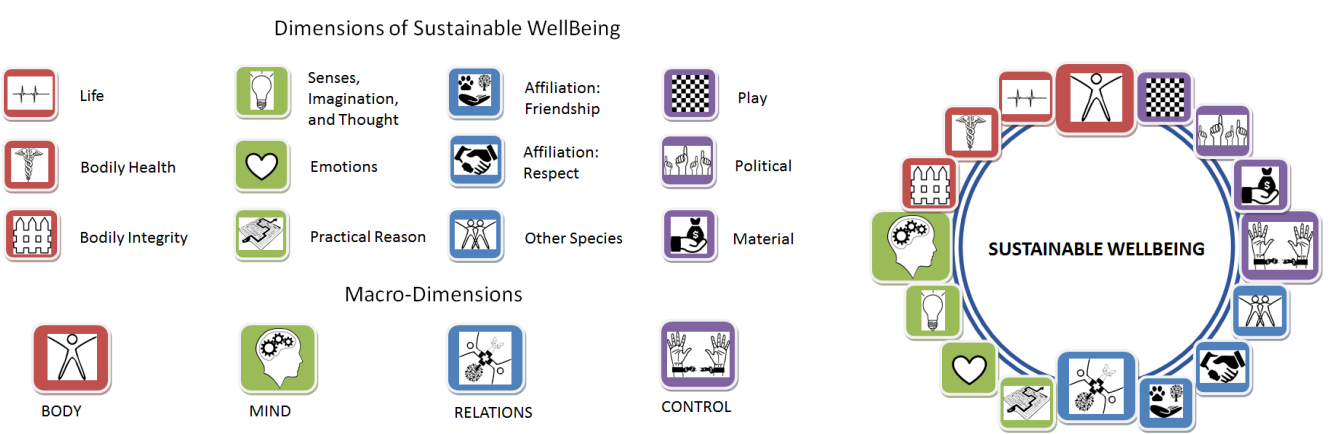

Figure 1. Dimensions of sustainable wellbeing. Source: own elaboration.

The macro-dimensions make up groupings of the dimensions of the central capabilities of M. Nussbaum. These are as follows: (1) Body: as an element that connects us physically with the world and that must be maintained as far as possible with health and bodily integrity until ones death. (2) Mind: Being able to think, feel emotions, and specify the reasoning of a good life and the virtues of what we should be and do. (3) Relation and (4) Control, which allow us to connect with society and with nature, in order to put into practice the virtues and our freedoms.

Each dimension was defined from what was described by M. Nussbaum, adding and adapting the respective descriptions for sustainable wellbeing. The 12 dimensions are described as follows:

\subsection{Macro-Dimensions and Dimensions}

\subsubsection{Macro-Dimension: Body}

- Life: Being able to live fully and responsibly until the end of a human life of normal duration or before life itself is so reduced that it is not worth living. To not die prematurely or in precarious conditions.

- Bodily health: Being able to have good health, including sexual and reproductive health; to be adequately nourished; and to have adequate shelter.

- Bodily integrity: Being able to move freely from place to place; to be secure against violent assault, including sexual assault and domestic violence; and having opportunities for sexual and/or reproductive satisfaction, as well as free choice in this regard. 


\subsubsection{Macro-Dimension: Mind}

- Senses, imagination, and thought: Being able to use the senses, to imagine, think, and reason - and to do these things in a "truly human" way, a way informed and cultivated by an adequate education that includes, but is not limited to, vehicular language and exchange with other communities. Being able to use imagination and thought for experimentation and production of works and acts of their own choosing, whether religious, literary, musical, or otherwise, as well as guaranteeing their rights to their own creation. Being able to use one's own mind in conditions protected by the guarantees of freedom of political and artistic expression, and by freedom of spiritual practice. Being able to have pleasurable experiences and to avoid non-beneficial pain.

- Emotions: Being able to feel attached to ourselves and other beings; to love those who love and care for us; to grieve at their absence; and, in general, to love, feel loved, and to grieve, as well as to experience longing, gratitude, and justified anger. Not having one's emotional development blighted by fear and anxiety. The following condition applies: defending this capability means defending, in turn, certain forms of human association that may prove crucial in its development.

- Practical reason: Being able to form a conception of the good, dream of an ideal, and critically reflect on the meaning of one's life (this ability entails the protection of freedom of conscience and religious observance).

\subsubsection{Macro-Dimension: Relations}

- Affiliation-friendship: Being able to live with and around others, to recognize and show concern for other human beings, to engage in various forms of social interaction, and to be able to imagine the situation of another (protecting this capability means protecting institutions that constitute and nourish such forms of affiliation, as well as protecting the freedom of assembly and political speech).

- Affiliation-respect: Having the social bases of self-respect and non-humiliation; being able to be treated as a dignified being whose worth is equal to that of others, forming a diverse and combined society. This entails provisions of nondiscrimination on the basis of race, socioeconomic status, failure, criminal history, sex, sexual orientation, ethnicity, caste, religion, ideology, age, generation, or physical or mental health status, as well as national origin.

- Other species: Being able to live with consideration and concern for and in relation to animals, plants, and the world of nature.

\subsubsection{Macro-Dimension: Control}

- Play: Being able to laugh and play sensibly, as well as enjoy recreational activities.

- Control over one's own environment-political: Being able to participate effectively in political choices that govern one's life; having the right of political participation without fear, involving the protection of freedom of speech and association.

- Control over one's own environment-material: Being able to own properties with money from lawful sources (both land and movable goods), and having property rights on an equal basis with others; having the right to create and seek employment on an equal basis with others; and having the freedom from unwarranted search and seizure. This involves being able to work as a human being, exercising practical reason, and entering into meaningful relationships of mutual recognition with other workers.

\subsection{Identification of the Indicators Associated with the Dimensions}

Once the dimensions were defined, information was sought from various data sources to incorporate the content of each dimension and move onto the next stages of analysis and evaluation. The most common data sources were international NGOs, indicators developed by private institutions, universities, and some official sources at the international level. Of these, the following are worth highlighting: (a) Latin American: Latinobarómetro and the LAPOP project, which contain an important data source for the region; (b) international: 
organizations such as the World Economic Forum, the World Bank, and various instances of the United Nations; (c) NGO: Cato Institute, The Heritage Foundation, and the Fraser Institute; (d) private companies: GALLUP and Google; and (e) some international indices, such as the Fragile State Index and the Social Progress Index. The choice of indicators was based on measurements that reflect the conditions that people have to be who they want to be and do what they value.

A second aspect that was considered is the treatment of measurements in positive and active terms. For example, variables such as "mortality" are not considered, but rather the perspective of "survival" is considered. An example of a variable not associated with the approach would be deaths caused by HIV. On the other hand, variables more closely associated with the approach would be, for example, the search for preventive information on HIV or the percentage of people infected with HIV who seek and receive ART drugs out of the total number of patients. That is, the variables are linked to "being able" to maintain life in terms of a normal duration by the individual, informing oneself about the disease in a preventive and responsible way or, once infected, voluntarily and responsibly taking ones medicine to try to lead a full life.

Each of the identified indicators were related to a dimension of sustainable wellbeing. Some indicators showed a relationship with more than one dimension. It is important to note that, in the sustainable wellbeing approach, all dimensions are equipotent (same weight or relevance). Furthermore, the dimensions are integrated, interrelated, and must work in harmony to guarantee wellbeing in the most comprehensive way possible.

\subsection{Analysis of the Indicators}

For the statistical analysis, multiple correspondence analysis (MCA) was selected, as it enhances the approach from the statistical philosophy in accordance with the approach philosophy. MCA is a multivariate and exploratory statistical analysis technique that is used to describe the relationships between variables and the categories assigned to them. Likewise, it is a technique recognized in the OECD Guide for the Constructing of Indicators [29], in addition to being widely used in indices, such as the OECD Social Institutions and Gender Index (SIGI) [30]. MCA was applied using the statistical software SPAD v5.5 (French acronym Système Portable de Analyse des Donnes).

All the variables in each dimension were combined [28] in their respective macrodimensions, and then all the macro-dimensions, until obtaining the conditions of the combined capabilities described by the Nussbaum approach [25].

The analysis by countries (or by any other unit of analysis) should consider three categories: low (1), medium (2), or high (3), of sustainable wellbeing (or, seen in reverse, of risk) in each selected indicator, according to the values obtained by the country. The results of the countries in each indicator are ordered from lowest to highest and, with their accumulated frequency, they are divided into three proportional parts $(33 \%, 66 \%, 100 \%)$ to determine the category in which the country is located. The category results from the location of the result in the respective third. Thus, between the three categories, there are reference limits, although they are undoubtedly fuzzy (though are reference limits, those that are awfully close to them could always have characteristics of both categories; therefore, it can be fuzzy).

Once the categories of the countries were obtained in each indicator, by dimension, MCA was carried out to obtain the score of the country by dimension (see Equation (1)), obtaining a summary measure called a coordinate. The coordinate indicates the contributionexplained by the inertia of the factors - of the categories of the indicators.

$$
S i=\sum_{q=1}^{Q} H j q a
$$

where:

$S i=$ sum of the coordinates of the $i$-th country 
Hjqa $=$ coordinate of the $i$-th country in the $j$-th category of the $q$-th variable for the factor $\alpha$.

$\alpha=1=$ the first factor that collects the highest percentage of variability.

Equation (1). Equation for the sum of the coordinates.

Each category of the indicator will be assigned a coordinate in the factorial plane (see Figure 2) and each country will be assigned a coordinate corresponding to its category in each indicator. To obtain the score for each country, the coordinates of the categories of the associated variables are added. Thus, a measure associated with the sustainable wellbeing conditions of each country is obtained for a specific dimension (see Figure 3). Finally, the Index (Z) is adjusted on a scale between [0; 10] (Equation (2)).

$$
Z i=\frac{S i-M i n S}{\operatorname{Max} S-\operatorname{Min} S} \times 10
$$

where:

$Z i=$ Value for the $i$-th country.

$\operatorname{Min} S=\min \{S 1, S 2, \ldots, S n\}$.

$\operatorname{Max} S=\max \{S 1, S 2, \ldots, S n\}$.

Equation (2). Equation to adjust the numerical scale.

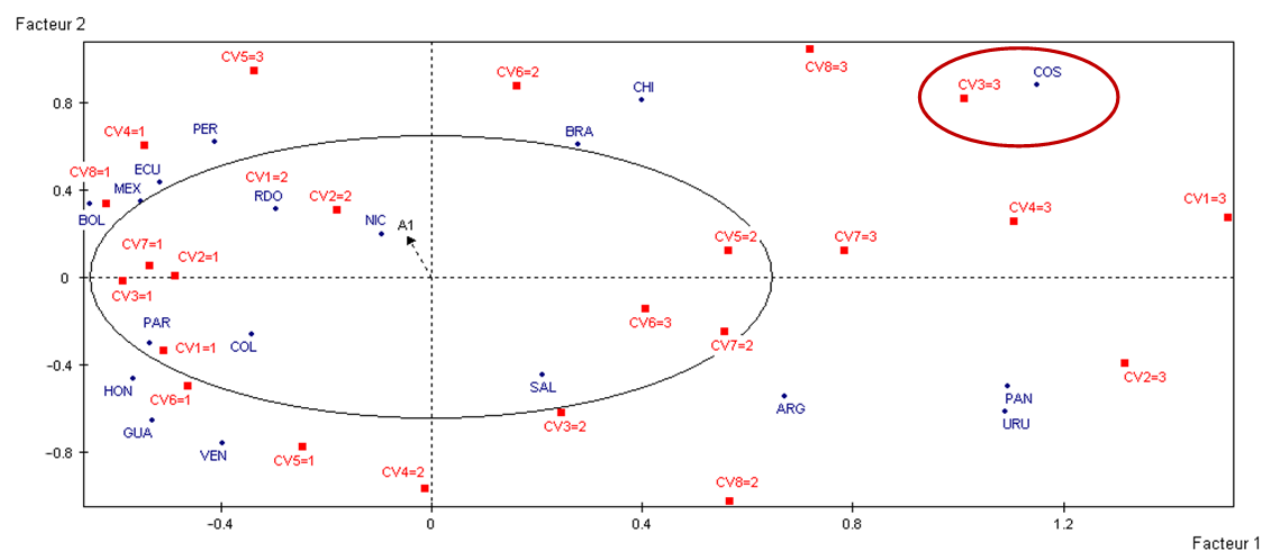

Figure 2. MCA (multiple correspondence analysis) factorial plane.

As it is an analysis by dimension, the favorable conditions of the results can be determined according to the sense of the data; that is, those closest to 10 would have a greater association with sustainable wellbeing.

Figure 2 shows an example of two factors associated with a dimension, where each indicator has been categorized into three levels. For example, Costa Rica (COS) is located on the plane surrounded by indicators (any $(\mathrm{CVn})$ ) with category 3 , which means that it has low risks or high favorable conditions of sustainable wellbeing.

Subsequently, the results of the corresponding dimensions were averaged for the analysis by macro-dimensions of each country and, finally, the results of the macro-dimensions were averaged to obtain the value of sustainable wellbeing for each country. 


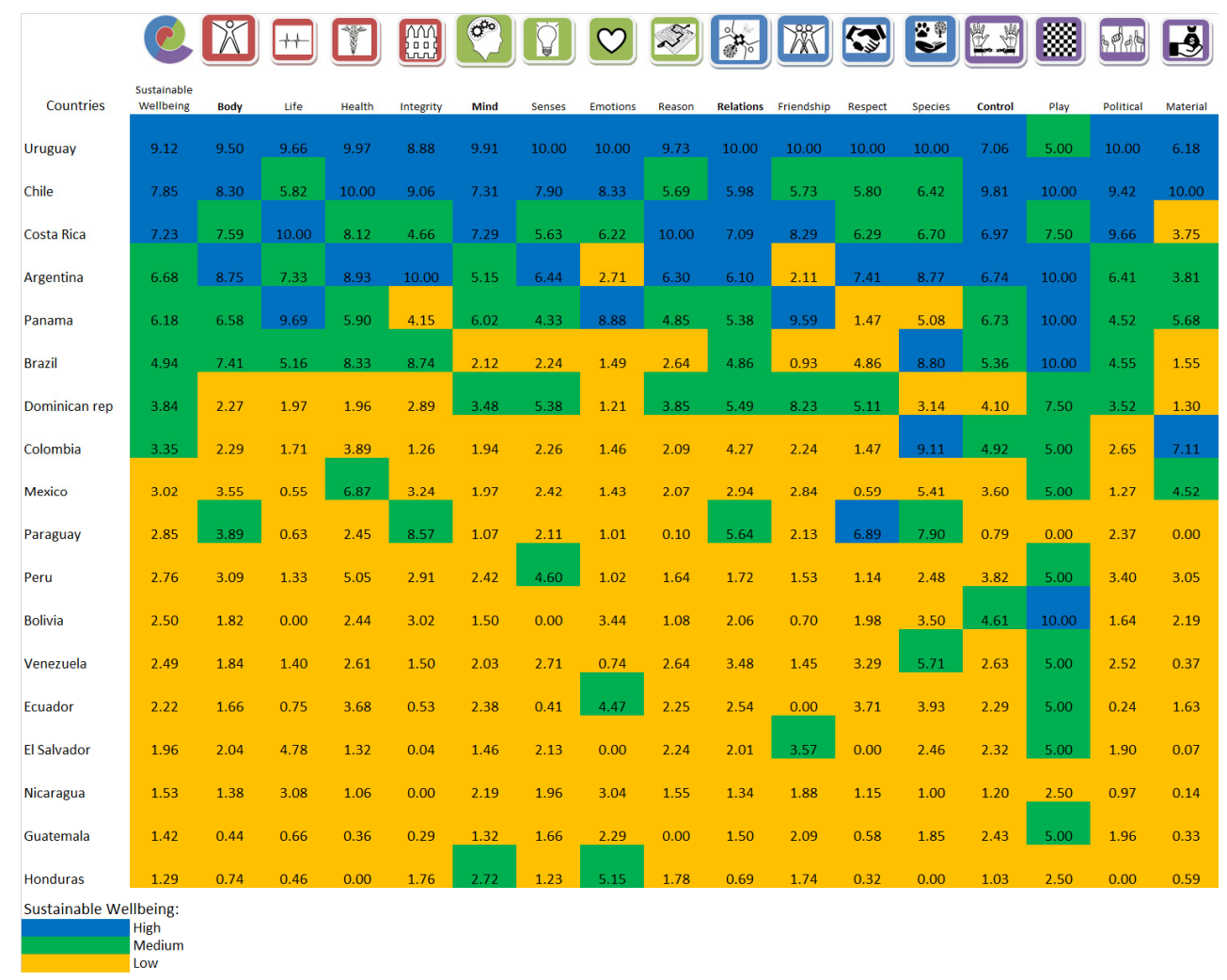

Figure 3. Results of sustainable wellbeing, macro-dimensions, and dimensions.

\section{Case Study: Results}

Latin America was considered because it is a geopolitical region with common historical and cultural characteristics, which facilitates comparison. Eighteen countries of the region were selected and those countries with an absence of more than $5 \%$ of the data from the total variables of all dimensions were excluded.

Two hundred and twenty-two data sources were consulted, which in turn contained numerous indicators (look at Table S1 in Supplementary Materials). Furthermore, 341 potential indicators were preselected from these data sources. It is worth remembering that the selection was based on three criteria: (1) relationship with the capabilities approach; (2) data as up-to-date as possible; and (3) with data for $95 \%$ of the countries in the selected region. Finally, 116 indicators were selected, distributed in each of the 12 dimensions (see Table S2 in Supplementary Materials).

Next, and as an example, the conformation of the life dimension is presented. The selected indicators were as follows: life expectancy at birth (CV1); people (\%) infected with HIV who seek and receive ART drugs from the total number of patients (CV2); index of general satisfaction with life (CV3); life purpose/full life (\%) (CV4); \% absence of severe depressive disorders (CV5); percentage of surviving children who received the two vaccines recommended by WHO (CV6); \% perception of quality medical care (CV7); and perception of the effectiveness of the application of various road safety regulations (CV8). As can be seen, there is a combination of objective and subjective indicators (see the Supplementary Materials. Table S3 contains the original data for each indicator, dimension, and macrodimension; Table S4 contains the adjusted data; Table S5 contains the categorized data; and Table S6 contains the respective coordinates, following the steps indicated in the methodological design).

For the life dimension, as seen in Figure 2, the indicators CV1, CV2, CV3, CV4, CV7, and CV8 are very significant (being far from the center of the plane) and are also very close to each other (related). This leads to the conclusion that they are an important component in explaining sustainable wellbeing in this dimension and particularly for the positioning of Costa Rica, Panama, and Uruguay. 
The results were satisfactory, with a percentage of variability of $33.59 \%$ for the first two factors, that is, it explains $1 / 3$ of the total variability. The first factor is constituted, mainly, by variables with high categories of sustainable wellbeing.

Figure 2 illustrates each variable "Cn" with its category level 1, 2, or 3; for example, $\mathrm{CV} 3$, in its high category " 3 ", is illustrated as CV3 $=3$, in this case being general satisfaction with life, with a result very close to that of Costa Rica. Countries very close to each other imply similarities in certain conditions, for example, Panama and Uruguay; the opposite applies to very distant countries. The same happens with the categories assigned to each indicator of the analysis, for example, $\mathrm{CV} 4=3$ with $\mathrm{CV} 3=3$. These countries, together with the respective categories of each indicator outside the circle on the coordinate axis, will be understood as those that are statistically very significant in explaining the results of the analysis.

Once the coordinates were obtained, according to the methodological design, we proceeded to the construction of the index that would allow to show the results for each country in the dimension. Thus, Figure 3 shows the results of the life dimension for the countries under study, where Costa Rica stands out as first in the ranking. The results in yellow indicate the low category, those in green indicate the medium category, and those in blue indicate the high category. The latter are the best positioned results by country in the life dimension of sustainable wellbeing.

In each of the remaining eleven dimensions, the same procedure was applied. Then, the result of the macro-dimension was calculated and, finally, with the result of the four macro-dimensions, its result was averaged to determine the final score of sustainable wellbeing. It is important to mention that, for each result (dimension, macro-dimension, and final score), the scales are adjusted (see Equation (2)) so that the results remain on a scale of [0-10] (see Figure 3).

The Latin American countries that were best positioned in the sustainable wellbeing measurement and that achieve the best balance for sustainability are Uruguay (9.12), Chile (7.85), and Costa Rica (7.23). It is understood that they are countries in which people have greater guarantees of having more opportunities to be who they want to be and do what they value in the present and in the future. In the case of Uruguay, favorable harmony can be noticed in the various dimensions, which boosts sustainability, unlike countries like Panama, which shows differentiated levels between the various dimensions.

\section{Discussion}

The discussion focuses on three aspects. The first is the concept of sustainable wellbeing and its relevance; the second is its sizing; and the third pertains to the method and its statistical measurement.

\subsection{About the Concept of Sustainable Wellbeing}

Since the end of the last century and based on a series of socio-political and technoeconomic transformations, to which climate change and now the COVID-19 pandemic have been added, a review of development approaches is necessary, including sustainable development. Sustainable wellbeing arises as a broad and comprehensive notion to contribute to a better world, as a way of carrying out social policy as well as individual life, because it starts from the people themselves, where they themselves become a key pieceor agents-of sustainability. In other words, this involves having a sense of individual responsibility and being able to give other generations a world with the best conditions so that they can be who they want to be and do what they value.

The obligatory question is, what are those conditions? A. Sen [26] raises it in terms of capabilities, when he mentions that sustainability is the boosting of the capabilities of the present, without compromising the capabilities of future generations. So, what conditions generate capabilities? These include democracy, education, family, property rights, the rule of law in general, and freedom, among others. They are conditions that in themselves generate virtuous circuits of sustainability. 
It is always important to highlight that sustainability is multidimensional. For example, economic sustainability can relate to the family, culture, and politics. These aspects must be economically sustainable; otherwise, what it generates is an unacceptable social debt. Furthermore, sustainability must have a political dimension; otherwise, it does not allow governance; Finally, sustainability much have a cultural dimension; otherwise, it leads to unacceptable tensions and, eventually, war. In the same way, one dimension should not be highlighted over another; there must be harmony between them, as well as a connection, in order to finally also be able to integrate a temporary vision of sustainability between the present and future.

The usual idea is that the welfare of the future depends on the present, but not the other way around - that the welfare of the present depends on how the future will be; this is one of the key aspects that must be considered conceptually, without being translated into an over-determination of the future based on the present.

In some perspectives, they even recommend separating the future from the present, as is the case of the Stiglitz-Sen-Fitoussi Commission [2], stating that including a wellbeing perspective with unfavorable risk scenarios would be counterproductive for people's current wellbeing. In other perspectives, the future depends on the present in an indirect way, as in the Better Life Index or Quality of Life of the Eurostat [31,32]. In others, the dependence is more direct, but in a limited way in dimensions. For example, in the SDG-2030 [33], freedom is absent, an indissoluble condition of the human being; however, the most usual idea is to limit the future to the current conditions of the dimensions associated with the environment, which only assume some dimensions related to future conditions, including the sustainable development approach.

Therefore, sustainability must be viewed in a multidimensional sense. If you want to have comprehensive wellbeing as part of justice, it is necessary to integrate the capabilities of the future as a multidimensional value of wellbeing in the present.

\subsection{The Dimensioning of Sustainable Wellbeing}

Sustainability and wellbeing in this work are approached from the capabilities approach through associated conditions (combined capabilities proposed by M. Nussbaum) [25]. In other words, the capacity to be sustainable-in terms of capabilities and opportunities, more than results - from which development is traditionally measured. Thus, to achieve sustainable wellbeing, the conditions for wellbeing to be sustainable over time must be considered, and these conditions are based on the capabilities of the present.

Upon having a defined concept, the next step is to obtain a proper dimensioning that can meet that concept. There are multiple references for the dimensions: Bhutan Gross Internal Happiness [34], John Finnis [35], Keshava Bhat [36], Max-Neef [23], Martha Nussbaum [25], Gabaldon Arnoldo [24], Stiglitz Commission- Sen-Fitoussi [2], Vision 2021 UAE [37], Angel Hernández and Zouleyma [38], Eurostat with the Quality of Life measurement [32,39], Sabina Alkire [40], Vision 2030 Saudi Arabia [41], the United Nations with the SDG2030 targets [33], and Good Living (Buen vivir/Suma Kawsay) [42], just to mention a few.

Of all these possible ways of adding dimensions to sustainable wellbeing, the focus of the central capabilities of M. Nussbaum [25] was adequate. The main reason is that they are based on essentialism, and promote universal values known as non-relative virtues $[43,44]$. If we are thinking of measuring sustainability both individually and globally, we must put aside cultural relativism. The Martha Nussbaum capabilities approach is ideal; regardless of the cultures and territorial and individual borders, all individuals want the same thing, that is, to have health, security, political participation, acquire material goods, relate to other people, feel emotions, meditate, enjoy nature, and laugh, among others. This becomes something fundamental if you want to make a statistical measurement at any scale and in any place to guarantee comparability, where, in addition, the problem of sustainability is already global or universal for all human beings and where cultural relativism does not 
have a place. It is worth saying that this idea is not fully shared by authors such as A. Sen [45] and S. Alkire [46].

Promoting universal values does not mean eliminating or belittling individual or local values, but simply that universal values should be the connection point of a minimum relationship between all of the communities on our planet, even considering relationships over time or between generations, for a goal of common interest. In this way, without the responsibility of each person and with a lack of coordination, we will never achieve effective changes to meet the needs of our planet, much less guarantee the survival of our own species [10].

\subsection{The Method and Measurement}

Outcome indicators are usually adopted in wellbeing measurements. In this study, measurements that reflect opportunities or rights were favored. The indicators selected for the analysis of sustainable wellbeing were access indicators, as they are conceptually more related to the capabilities approach. This is not the same as measuring electoral participation in elections versus electoral freedom. The first is not associated with a capabilities approach.

For the analysis of sustainable wellbeing, in theory, any statistical procedure can be used, including a simple average. In this case, we deprived the criterion of guaranteeing the isomorphism between the statistical procedure and the philosophy of the approach. Among all the possible routes for statistical analysis, and in the search to have a reconciliation between the philosophical approach and the statistical technique, MCA was selected. MCA is an exploratory multivariate statistical analysis technique that helps to describe the relationships between variables and the categories assigned to them. It allows to identify the limits of sustainability, which are complex and abstract. These limits are mentioned in Luhmann [47], Fitoussi [48], Beck [9], the Stiglitz-Sen-Fitoussi Commission [2], and Martha Nussbaum [25].

In sustainable wellbeing, all dimensions are equal, that is, there is no one dimension that is more relevant than another-as was the case in the 1970s with economic dimension and where regression models have great influence. Additionally, in the approach to sustainable wellbeing, harmony, interrelationships, and integration between all dimensions are necessary. In this sense, regression techniques would be ruled out, because here, there are no pre-established dependent and independent variables. Sustainable wellbeing seeks the linkage or association of all variables.

\section{Conclusions}

The concept of sustainable wellbeing is an alternative approach to Human Development and the Sustainable Development Goals (SDGs) by 2030. It can certainly be integrated into the current discussion on sustainable human development, where not only are the values of its conception and its dimensioning fundamental, but the feasibility of its operationalization has also been demonstrated to be able to put them into practice, measuring and monitoring the associated policies.

Supplementary Materials: The following are available online at https: / www.mdpi.com/article / 10.3390/su132112202/s1, in format Excel: Table S1 contains the list of sources consulted. Table S2 contains the list of the 116 selected indicators, divided by macro-dimensions and dimensions. Table S3 contains the original data for each indicator, dimension, and macro-dimension. Table S4 contains the adjusted data, Table S5 contains the categorized data, and Table S6 contains the respective coordinates, following the steps indicated in the methodological design.

Author Contributions: Conceptualization, all authors; methodology, J.P.; validation, M.P.C.; formal analysis, all authors; investigation, all authors; data curation, J.P.; writing-original draft preparation, J.P.; writing - review and editing, all authors; visualization, J.P. All authors have read and agreed to the published version of the manuscript.

Funding: This research received no external funding. 
Institutional Review Board Statement: Not applicable.

Informed Consent Statement: Not applicable.

Data Availability Statement: Not applicable.

Conflicts of Interest: The authors declare no conflict of interest.

\section{References}

1. European Commission. GDP and Beyond. Measuring Progress in a Changing World; European Commission: Brussels, Belgium, 2009. Available online: https:/ / eur-lex.europa.eu/LexUriServ/LexUriServ.do?uri=COM:2009:0433:FIN:EN:PDF (accessed on 6 May 2021).

2. Stiglitz-Sen-Fitoussi Commission. Report by the Commission on the Measurement of Economic Performance and Social Progress; Presidency of the French Republic: Paris, France, 2009. Available online: https:// ec.europa.eu/eurostat/documents/8131721/81 31772/Stiglitz-Sen-Fitoussi-Commission-report.pdf (accessed on 4 May 2021).

3. UNDP. Human Development Report 1990: Concept and Measurement of Human Development; UNDP: New York, NY, USA, 1990. Available online: http:/ / www.hdr.undp.org/en/reports/global/hdr1990 (accessed on 4 May 2021).

4. UNEP. Cocoyoc Declaration Adopted by the Participants in the UNEP/UNCTAD Symposium, Patterns of Resource Use, Environment and Development Strategies, Cocoyoc, Mexico, 8-12 October 1974; UNEP: Cocoyoc, Mexico, 1978. Available online: https:/ / digitallibrary. un.org/record/838843? ln=es (accessed on 4 May 2021).

5. European Parliament Resolution. Climate and Environmental Emergency. 28 November 2019 (2019/2930(RSP)). Available online: https://www.europarl.europa.eu/doceo/document/TA-9-2019-0078_EN.html (accessed on 4 May 2021).

6. European Union. The European Green Deal; European Union: Brussels, Belgium, 2019. Available online: https:/ / ec.europa.eu/ info/strategy/priorities-2019-2024/european-green-deal_en (accessed on 4 May 2021).

7. Proposal for a Regulation of the European Parliament and of the Council Establishing the Framework for Achieving Climate Neutrality and Amending Regulation; (EU) 2018/1999 (European Climate Law). Available online: https: / /ec.europa.eu/clima/ policies/eu-climate-action/law_en (accessed on 4 May 2021).

8. Gobierno de España. Acuerdo de Consejo de Ministros (21 January 2020), Por el que se Aprueba la Declaración del Gobierno ante la Emergencia Climática y Ambiental; Gobierno de España: Madrid, Spain, 2020. Available online: https://www.lamoncloa.gob.es/ consejodeministros/resumenes/Documents/2020/210120-Declaracion_emergencia-climatica.pdf (accessed on 20 May 2021).

9. Beck, U. La Sociedad del Riesgo Global; Siglo Veintiuno: Madrid, Spain, 1999.

10. Bauman, Z. Mortalidad, Inmortalidad y Otras Estrategias de Vida; Ediciones Sequitur: Madrid, Spain, 1992.

11. Gudynas, E. Debates sobre el desarrollo y sus alternativas en América Latina: Una breve guía heterodoxa. In Más allá del Desarrollo; Grupo Permanente de Trabajo Sobre Alternativas al Desarrollo, Ed.; Fundación Rosa Luxemburgo y Abya Yala: Quito, Ecuador, 2011; pp. 21-54. Available online: http://gudynas.com/publicaciones/capitulos/GudynasDesarrolloGuiaHeterodoxaFRLQuito1 1.pdf (accessed on 4 May 2021).

12. Meadows, D.; Meadows, D.; Randers, J.; Behrens, W. The Limits to Growth; A Report for the Club of Rome's Project on the Predicament of Mankind; Yale University Press: New Haven, CT, USA, 1972.

13. Sur Commission. Hacia una Nueva Forma de Medir el Desarrollo; Report of the International Meeting on More Effective Development Indicators; Oficina de la Comisión Sur en Venezuela: Caracas, Venezuela, 1989.

14. Brundtland Commission. Our Common Future. In Report of the World Commission on Environment and Development; United Nations: New York, NY, USA, 1987. Available online: https:/ / digitallibrary.un.org/record/139811?ln=es\#record-files-collapse-header (accessed on 9 February 2017).

15. United Nations. Transforming Our World: The 2030 Agenda for Sustainable Development; United Nations: New York, NY, USA, 2015. Available online: https:/ / unctad.org/system/files/official-document/ares70d1_en.pdf (accessed on 4 May 2021).

16. United Nations. Paris Agreement. 2015. Available online: https://unfccc.int/sites/default/files/english_paris_agreement.pdf (accessed on 4 May 2021).

17. United Nations. A New Global Partnership: Eradicate Poverty and Transform Economies through Sustainable Development; The Report of the High-Level Panel of Eminent Persons on the Post-2015 Development Agenda; United Nations: New York, NY, USA, 2013.

18. United Nations. The Future We Want. 2012. Resolution Adopted by the General Assembly on 27 July 2012. Available online: https:/ / www.un.org/en/development/desa/population/migration/generalassembly/docs/globalcompact/A_RES_ 66_288.pdf (accessed on 4 May 2021).

19. COP25. Acuerdo de la Cumbre del Clima COP25: Chile-Madrid Tiempo de Actuar, Madrid, Spain. 2019. Available online: https://www.miteco.gob.es/es/prensa/20191215_np_cop25_final_tcm30-505711.pdf (accessed on 4 May 2021).

20. IPCC. Global Warming of $1.5^{\circ} \mathrm{C}$; An IPCC Special Report on the Impacts of Global Warming of $1.5^{\circ} \mathrm{C}$ above Pre-Industrial Levels and Related Global Greenhouse Gas Emission Pathways, in the Context of Strengthening the Global Response to the Threat of Climate Change; IPCC: Geneva, Switzerland, 2018.

21. Rachel, C. Silent Spring; Houghton Mifflin Harcourt: New York, NY, USA, 1962. Available online: http://www.rachelcarson.org/ SilentSpring.aspx (accessed on 4 May 2021).

22. Francisco, P. Laudato Si, Sobre el Cuidado de la Casa Común; Editorial San Pablo: Madrid, Spain, 2015. 
23. Max-Neef, M.A.; Elizalde, A.; Hopenhayn, M. Desarrollo a Escala Humana. Conceptos, Aplicaciones y Algunas Reflexiones; Icaria: Barcelona, Spain, 1994. Available online: https://www.max-neef.cl/descargas/Max_Neef-Desarrollo_a_escala_humana.pdf (accessed on 4 May 2021).

24. Arnoldo, G. Desarrollo Sustentable. La salida de América Latina; Editorial Grijalbo: Caracas, Venezuela, 2006.

25. Nussbaum, M. Creating Capabilities: The Human Development Approach; The Belknap Press of Harvard University Press: Cambridge, MA, USA, 2011.

26. Sen, A. The Ends and Means of Sustainability. J. Hum. Dev. Capab. 2013, 14, 6-20. [CrossRef]

27. Levy-Carciente, J.; Phélan, S.; Perdomo, M. Indicadores Multidimensionales de Desarrollo. Base de Datos Para Apoyar Las Políticas Públicas (Fase 1); SELA: Caracas, Venezuela, 2020. Available online: http:/ /www.sela.org/es/centro-de-documentacion/base-dedatos-documental/bdd/66102/indicadores-multidimensionales-de-desarrollo (accessed on 4 May 2021).

28. International Organization for Standardization (ISO). Risk Management: Principles and Guidelines, ISO 31000; ISO Press: Geneva, Switzerland, 2009.

29. OECD. Handbook on Constructing Composite Indicators. Methodology and User Guide; OECD: Paris, France, 2008.

30. OECD. Synthesis Report. Social Institutions and Gender Index (SIGI); OECD: Paris, France, 2014. Available online: www.genderindex. org (accessed on 4 May 2021).

31. OECD. Better Life Index-Executive Summary; OECD: Paris, France, 2014. Available online: http:/ /www.oecdbetterlifeindex.org/ media/bli/documents/BLI_executive_summary_2014.pdf (accessed on 4 May 2021).

32. Eurostat, European Statistical System (ESS). Sponsorship Group on Measuring Progress, Well-being and Sustainable Development; Final Report adopted by the European Statistical System Committee; Eurostat: Luxembourg, 2011.

33. United Nations. Indicators and a Monitoring Framework for Sustainable Development Goals: Launching a data Revolution for the SDGs; A Report to the Secretary-General of the United Nations by the Leadership Council of the Sustainable Development Solutions Network; United Nations: New York, NY, USA, 2015.

34. NDP Steering Committee and Secretariat. Happiness: Towards a New Development Paradigm: Report of the Kingdom of Bhutan; Royal Government of Bhutan: Thimphu, Bhutan, 2013.

35. Finnis, J. Natural Law and Natural Rights; Oxford University Press: New York, NY, USA, 1980.

36. Keshava, B. Las Bases del Naturismo: Naturaleza y Bienestar Humano; Ediciones Vivir Mejor: Caracas, Venezuela, 1991.

37. UAE. Vision 2021 United Arab Emirates. Web Oficial. 2010. Available online: https://www.vision2021.ae/en/ (accessed on 3 February 2018).

38. Hernández, A.; Escala, Z. Enfoques de la Capacidad y el Desarrollo Humano. Origen, Evolución y Aplicaciones; Editor PNUD Venezuela y Total Venezuela: Caracas, Venezuela, 2011.

39. INE-España. Metodología de Indicadores de Calidad de Vida. 2016. Available online: https://www.ine.es/ss/Satellite?blobcol=

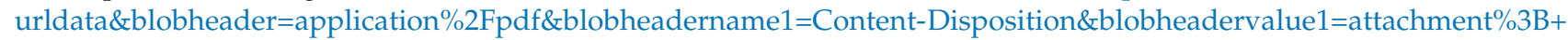
filename\%3DMetodologia_ICV_2021.pdf\&blobkey=urldata\&blobtable=MungoBlobs\&blobwhere=357\%2F787\%2FMetodologia_ ICV_2021.pdf\&ssbinary=true (accessed on 4 May 2021).

40. Sabina, A. Well-Being, Happiness, and Public Policy. OPHI. Research in Progress Series 2013; Research in Progress 37a. 2013. Available online: https:/ / ophi.org.uk/ophi-research-in-progress-37a/ (accessed on 18 May 2021).

41. Kingdom of Saudi Arabia. Vision 2030 for the Kingdom of Saudi Arabia. Web Official; 2015. Available online: https://www. vision2030.gov.sa/ (accessed on 3 February 2018).

42. Arias, F.; Phélan, M. La medición del buen vivir rural. Estudio de caso en el Cantón Pucará, Provincia de Azuay, Ecuador. Rev. Venez. Análisis Coyuntura. 2016, 22, 111-134.

43. Nussbaum, M. Virtudes no relativas: Un enfoque aristotélico. In Nussbaum Martha E Sen Amartya (compiladores), La Calidad de Vida; Fondo de Cultura Económica: México City, Mexico, 1996.

44. Nussbaum, M. Human functioning and social justice: In defense of Aristotelian essentialism. Polit. Theory 1992, 20, 202-246. [CrossRef]

45. Sen, A. Desarrollo y Libertad; Editorial Planeta: Barcelona, España, 1999.

46. Sabina, A. Dimensions of Human Development. World Dev. 2002, 30, 181-205.

47. Luhmann, N. Sociología del Riesgo; Universidad Iberoamericana, Ed.; Editorial Triana: México City, Mexico, 1992.

48. Fitoussi, J.-P.; Malik, K. Choices, Capabilities and Sustainability; Occasional Paper; Human Development Report Office, United Nations: New York, NY, USA, 2013. Available online: http:/ /hdr.undp.org/sites/default/files/hdro_malik_fitoussi.pdf (accessed on 18 May 2021). 